\title{
Radiocarbon in food: a non-problem of health effects
}

\author{
J. van der Plicht $\cdot$ J. P. M. Beijers
}

Received: 14 September 2009/Accepted: 13 November 2009/Published online: 15 December 2009

(C) The Author(s) 2009. This article is published with open access at Springerlink.com

\begin{abstract}
Recently it has come to our attention that a paper was published in this journal entitled "recycling greenhouse gas fossil fuel emissions into low radiocarbon food products to reduce human genetic damage" (Williams in Environ Chem Lett 5:197-202, 2007). In this article, it is argued that food grown in a greenhouse is healthier for people, when the greenhouse is fertilised with $\mathrm{CO}_{2}$ prepared from fossil fuels. In this comment, however, we argue that the effect on human health is completely negligible.
\end{abstract}

\section{Keywords Radioactivity · Food · Greenhouse}

One of the radioactive isotopes that occur in nature is ${ }^{14} \mathrm{C}$ or Radiocarbon. It has a natural abundance of ${ }^{14} \mathrm{C} /{ }^{12} \mathrm{C}=1.2 \times 10^{-12}$ and a halflife of 5,730 years (e.g., Mook 2006). Radiocarbon is thus present in all forms of natural carbon, including food consumed by humans and animals. Since fossil $\mathrm{CO}_{2}$ is of geological age, all ${ }^{14} \mathrm{C}$ has decayed, and the gas is free of Radiocarbon. Hence, plants that are growing in an environment with an excess of fossil $\mathrm{CO}_{2}$-like greenhouses indeed are depleted in ${ }^{14} \mathrm{C}$. This is well known in the community of ${ }^{14} \mathrm{C}$ laboratories. For example, the Groningen ${ }^{14} \mathrm{C}$ laboratory has tested tomatoes grown in greenhouses; tomatoes fresh on the market dated to 1,300 years ago. The same is true for the famous Dutch

J. van der Plicht $(\bowtie)$

Center for Isotope Research, Groningen University, Groningen,

The Netherlands

e-mail: j.van.der.plicht@ rug.nl

J. P. M. Beijers

Kernfysisch Versneller Instituut, Groningen University,

Groningen, The Netherlands flowers grown in greenhouses; they are less radioactive in ${ }^{14} \mathrm{C}$ than flowers grown outside, and are thus centuries old on the Radiocarbon timescale. This phenomenon is also observed and discussed by Williams (www.radiocarb.com) for soybeans.

Thus, greenhouse grown plants and food sources with a source of fossil fuel-derived $\mathrm{CO}_{2}$ contain less ${ }^{14} \mathrm{C}$ than their naturally grown counterparts. Obviously, this means that a person consuming a consistent diet of ${ }^{14} \mathrm{C}$ depleted food during his or her lifetime is exposed to less radiation from internal ${ }^{14} \mathrm{C}$ sources.

Williams (2007) calculates the number of decays over a human lifespan, which indeed is a large number. Subsequently, the biological impact due to DNA damage is estimated.

This calculation is in itself correct but that does not mean that there is a positive health effect. What is missing from the argument is a calculation of the radiation dose from ${ }^{14} \mathrm{C}$, natural or depleted, the effect of this dose on human health, and a comparison with other radioactive sources in the environment. Not surprisingly, such a calculation shows that the radiation dose from natural ${ }^{14} \mathrm{C}$ is in itself completely negligible. Even more so for food grown in greenhouses under fossil $\mathrm{CO}_{2}$, depleted in ${ }^{14} \mathrm{C}$.

The natural radioactivity of ${ }^{14} \mathrm{C}$ is $226 \mathrm{~Bq} / \mathrm{kgC}$ (e.g., Mook 2006). The halflife is 5,730 years, and ${ }^{14} \mathrm{C}$ is a lowenergy beta-emitter (max. $156 \mathrm{keV}$ ). The effects of this radioactivity on humans are given by the International Commission on Radiological Protection, ICRP-68 (1995). According to this authority, a "standard person" has a ${ }^{14} \mathrm{C}$ equilibrium activity of $3,500 \mathrm{~Bq}$, and the biological halflife is 40 days. From these numbers, one can calculate that the ${ }^{14} \mathrm{C}$ intake is $2.22 \times 10^{4} \mathrm{~Bq} /$ year.

The dose rate conversion coefficient for ${ }^{14} \mathrm{C}$ is $5.8 \times 10^{-10} \mathrm{~Sv} / \mathrm{Bq}$, for both ingestion and inhalation. 
Thus, one derives that the effective dose rate for ${ }^{14} \mathrm{C}$ intake is $13 \mu$-Sv/year. This is about $1 \%$ of the annual dose rate from natural radioactivity, which is generally taken as $1 \mathrm{~m}$-Sv/year. Thus, of all radioactivity exposure due to natural sources, the contribution of ${ }^{14} \mathrm{C}$ can be totally neglected. It is, in effect, a non-problem.

This can also be seen by the following illustrative example calculation.

Vegetables such as soybeans consist mainly of water; for their carbon content, we can assume a general number of $5 \%$. From the natural activity of $226 \mathrm{~Bq} / \mathrm{kgC}$ and the conversion factor of $5.8 \times 10^{-10} \mathrm{~Sv} / \mathrm{Bq}$, one can easily calculate that one has to consume for a year long $400 \mathrm{~kg}$ of vegetables per day, in order to get the natural background exposure of $1 \mathrm{~m}$-Sv/year. It seems to us that such a consumption pattern would lead to other more severe negative health effects than caused by ${ }^{14} \mathrm{C}$ radioactivity.

This is calculated for the natural ${ }^{14} \mathrm{C}$ concentration. For greenhouse-depleted ${ }^{14} \mathrm{C}$, the effect is obviously even less significant. In other words, depleting the ${ }^{14} \mathrm{C}$ content by $\mathrm{CO}_{2}$ in a greenhouse by any practical amount does not contribute in a significant way to more healthy food sources.

We note that in the recent past, the ${ }^{14} \mathrm{C}$ content in nature has been increased by anthropogenic causes, up to a factor of 2 . This occured globally by atmospheric nuclear bomb testing during the 1950s and 1960s (e.g., Levin and
Hesshaimer 2000) and locally because of the Chernobyl accident in 1986 (e.g., Kovalyukh et al. 1998).

Even then one could still eat $200 \mathrm{~kg}$ of vegetables per day. Obviously, this only concerns ${ }^{14} \mathrm{C}$ dose rates. Atmospheric nuclear explosions and the Chernobyl accident also released much more dangerous radioactive isotopes in the environment which are not safe for consumption and which are not discussed here.

Open Access This article is distributed under the terms of the Creative Commons Attribution Noncommercial License which permits any noncommercial use, distribution, and reproduction in any medium, provided the original author(s) and source are credited.

\section{References}

ICRP-68 (1995) Dose coefficients for intakes of radionuclides by workers. Ann ICRP 24/4 (Elsevier, ISBN: 978-0-08-042651-8)

Kovalyukh NN, Skripkin VV, van der Plicht J (1998) ${ }^{14} \mathrm{C}$ in the hot zone around chernobyl. Radiocarbon 40:391-397

Levin I, Hesshaimer V (2000) Radiocarbon-a unique tracer of global carbon cycle dynamics. Radiocarbon 42:69-80

Mook WG (2006) Introduction to isotope hydrology. Taylor and Francis, London ISBN: 0-415-38197-5

Williams CP (2007) Recycling greenhouse gas fossil fuel emissions into low radiocarbon food products to reduce human genetic damage. Environ Chem Lett 5:197-202 